\title{
5-Hydroxytryptamine Receptor 2C
}

National Cancer Institute

\section{Source}

National Cancer Institute. 5-Hydroxytryptamine Receptor 2C. NCI Thesaurus. Code C115018.

5-hydroxytryptamine receptor $2 \mathrm{C} \mathrm{(458} \mathrm{aa,} \sim 52 \mathrm{kDa}$ ) is encoded by the human HTR2C gene. This protein is involved in serotonin-mediated neurotransmission pathways. 